Canadian Journal of Fisheries and Aquatic Sciences, 1993, v.50, n.1, pp. 88-96.

Print ISSN: 0706-652X

Online ISSN: $1205-7533$

DOI: $10.1139 / \mathrm{f} 93-011$

http://pubs.nrc-cnrc.gc.ca/rp-ps/journalDetail.jsp?jcode=cjfas\&lang=eng

http://article.pubs.nrc-

cnrc.gc.ca/RPAS/rpv?hm=HInit\&calyLang=eng\&journal=cjfas\&volume=50\&afpf=f93-011.pdf (C) 1993 National Research Council of Canada 


\title{
Using Growth/Mortality Trade-offs to Explore a Crayfish Species Replacement in Stream Riffles and Pools
}

\author{
Martha E. Mather' and Roy A. Stein \\ Aquatic Ecology Laboratory, Department of Zoology, The Ohio State University, Columbus, OH 43212-1194, USA
}

Mather, M. E., and R. A. Stein. 1993. Using growth/mortality trade-offs to explore a crayfish species replacement in stream riffles and pools. Can. J. Fish. Aquat. Sci. 50: 88-96.

\begin{abstract}
A crayfish species replacement is underway in Ohio streams. We explore how growth, mortality, habitat use, and size influence the replacement of Orconectes sanborni by O. rusticus. In field cages, we assessed growth of crayfish. Both species grew faster when confined to riffles and $O$. rusticus grew faster than $O$. sanborni in this fast-water habitat. In another experiment, we tethered crayfish in riffles, shallow pools $(<40 \mathrm{~cm})$, and deep pools $(>40 \mathrm{~cm})$ to assess mortality. After $8 \mathrm{~d}$, more crayfish were eaten in deep pools than in riffles or shallow pools. Given this finding, we predicted that crayfish should preferentially occupy high-growth, low-mortality riffles. To test this hypothesis, we quantified crayfish habitat use in sympatric streams, with and without fish predators. Crayfish did not prefer riffles. Apparently, juvenile crayfish do not assess specific benefits and costs using only food and fish predators. Other costs associated with riffles (e.g. passive drift, terrestrial predators, summer desiccation, physiological cost of position maintenance, etc.) must reduce riffle use. In addition, $O$. rusticus grows larger than $O$. sanborni. Because size confers advantages in biotic interactions, this critical finding may be the key to the replacement.
\end{abstract}

La substitution d'une espèce d'écrevisse s'effectue actuellement dans des cours d'eau de l'Ohio. Nous examinons comment le croissance, la mortalité, l'utilisation de Yhabitat et la taille influent sur la substitution d'Orconectes sanborni par $O$. rusticus. Nous avons étudié sur le terrain la croissance des écrevisses en cage. Les deux espèces se sont développées plus rapidement lorsqu'elles étaient confinées à des rapides, et le taux de croissance $d^{\prime} O$. rusticus était plus élevé que celui $d^{\prime} O$. sanborni dans ce type d'habitat en eau vive. Au cours d'une autre expérience, nous avons confiné des écrevisses dans des rapides, des étangs peu profonds $(<40 \mathrm{~cm})$ et des étangs profonds $(>40 \mathrm{~cm})$ afin d'en évaluer la mortalité. Après 8 jours, les prédateurs avaient consommé plus d'écrevisses dans les étangs profonds que dans les rapides ou les étangs peu profonds. D'après ces résultats, nous avons émis l'hypothèse selon laquelle les écrevisses fréquentent de préférence les rapides où elles ont un rythme de croissance élevé et un faible taux de mortalité. Pour vérifier cette hypothèse, nous avons quantifié l'utilisation de l'habitat par l'écrevisse dans des cours d'eau sympatriques, avec et sans poissons prédateurs. Nous n'avons pas observé de préférence pour les rapides chez les écrevisses. II semble que les écrevisses juvéniles n'évaluent pas les avantages et les désavantages particuliers uniquement en fonction de la nourriture et des poissons prédateurs. D'autres facteurs négatifs liés aux rapides (par exemple, la dérive passive, les prédateurs terrestres, le dessèchement estival, le coût physiologique du maintien de la position, etc.) doivent diminuer l'utilisation des rapides. De plus, $O$. rusticus atteint une taille supérieure à celle $d^{\prime} O$. sanborni. Étant donné que la taille représente un avantage dans les interactions biotiques, cette importante découverte peut constituer l'élément clé de la substitution.

Received February 5, 1992

Accepted /uly 8, 1992

(JB394)

Reçu le 5 février 1992

Accepté le 8 juillet 1992

A species replacement is currently underway in central Ohio streams. Naturally occurring in Indiana, Kentucky, and western Ohio, Orconectes rusticus, a large, aggressive crayfish, is becoming increasingly common outside its native range and has been linked to declines of native crayfishes in Ontario (Crocker and Barr 1968; Berrill 1978), Wisconsin (Capelli 1982; Lodge et al. 1986; Olsen et al. 1991), and Ohio (Turner 1926; Jezerinac 1982; Butler and Stein 1985). Herein, we explore habitat-specific growth and mortality of $O$. rusticus and $O$. sanborni. If differential use of riffles and pools results in differential growth or mortality for either species, then habitat selection could provide insight into the replacement.

Without predators, animals should select habitats that provide the greatest net energetic return (Sih 1982a; Werner et al.

\footnotetext{
'Present address: Massachusetts Cooperative Fish and Wildlife Research Unit. Department of Forestry and Wildlife Management, Holdsworth Natural Resource Center, University of Massachusetts, Amherst. MA 01003, USA.
}

1983b). Predators may alter prey habitat use by forcing prey into habitats where they are less vulnerable (Fraser and Cerri 1982; Cooper 1984; Power et al. 1985; Foster et al. 1988). Habitat choice, in fact, may result from an explicit trade-off between predation risk and growth or feeding rates (Sih 1980; Mittelbach 1981; Cerri and Fraser 1983; Werner and Gilliam 1984; Holomuzki 1986; Gilliam and Fraser 1987; Holbrook and Schmitt 1988: Werner and Hall 1988). Predators also can reduce habitat profitability by reducing prey activity (Stein and Magnuson 1976; Sih 1982b; Holomuzki and Short 1988), feeding rate (Milinski and Heller 1978; Dill and Fraser 1984; Power et al. 1985; Prejs 1987), and ultimately growth (Rasmussen 1987; Dixon and Baker 1988). Inter- and intraspecific competition also may modify habitat choice. For example, superior competitors (Bovbjerg 1970) and larger congeners (Butler and Stein 1985; Rabeni 1985) modify crayfish distribution. Thus, habitat use depends on food, predators, competitors, as well as other sources of mortality. 
Table 1. Possible advantages and disadvantages of rifte, shallow pool. and deep pool for juvenile crayfish in headwater streams. + indicates a potential positive effect for craytish; - indicates a potential negative effect.

\begin{tabular}{llll}
\hline \hline & & \multicolumn{2}{c}{ Pool } \\
\cline { 3 - 4 } & Riffle & Shallow & Deep \\
\hline $\begin{array}{llll}\text { Abiotic features } \\
\text { Current }\end{array}$ & Fast & Slow & Slow \\
& $(-)$ & $(+)$ & $(+)$ \\
Passive Drift & Yes & No & No \\
& $(-)$ & $(+)$ & $(+)$ \\
Summer Drying & Yes & Yes & No \\
& $(-)$ & $(-)$ & $(+)$ \\
Percent Cover & Often high & Could be limited by sandy \\
& $(+)$ & patches over & entire pool \\
& & $(-)$ & \\
Biotic features & & & \\
Fish predators & No & No & Yes \\
& $(+)$ & $(+)$ & $(-)$ \\
Terrestrial Predators & Yes & Yes & No \\
& $(-)$ & $(-)$ & $(+)$ \\
Insect abundance & Can be high & Low & Low \\
& $(+)$ & $(-)$ & $(-)$ \\
Addult crayfish & Present & Present & Present \\
& $(-)$ & $(-)$ & $(-)$ \\
\hline
\end{tabular}

Differences in physical characteristics between pools and riffles affect stream animal distribution and abundance (Huryn and Wallace 1987a). Riffles and pools differ consistently in physical habitat structure and fish community composition (Schlosser 1982) (Table 1). Riffles are shallower, faster, and often have more aquatic insects than pools (Schlosser 1987; Schlosser and Ebel 1989; True 1990); furthermore, low-order, midwestern stream riffles rarely have fish predators. An abundance of high-quality food and absence of fish predators should attract juvenile crayfish to riffles. Conversely, terrestrial predation, desiccation in midsummer, aggression-induced passive drift, and position maintenance may be costs associated with high-velocity riffles. Thus, crayfish residing in stream riffles and pools may experience differences in growth and mortality rates. Crayfish habitat use should reflect these benefits and costs.

To assess if habitat use could contribute to the replacement of $O$. sanborni by $O$. rusticus, we pursued the following objectives. First, using field cages, we quantified growth of the two crayfishes in riffles and pools. Second, using tethering experiments, we measured crayfish mortality in riffles and pools. Third, based on these estimates of habitat-specific growth and mortality, we made predictions about how crayfish should be distributed across habitats. Finally, to test these predictions, we sampled habitat-specific crayfish density and size in the field.

\section{Methods}

\section{Habitat-Specific Growth}

In field growth experiments, three sites (one site $=$ one riffle and one pool) in Raccoon Creek (Licking County, Ohio), a second-order stream of the Licking River drainage, were used (Table 2). To compare growth between riffles and pools, crayfish were enclosed in $0.74 \mathrm{~m}$ (long) $\times 0.30 \mathrm{~m}$ (wide) $\times$ $0.15 \mathrm{~m}$ (high) cages; water flowed through upstream and downstream ends which were covered by $5-\mathrm{mm}^{2}$ hardware cloth. Substrate, taken from the stream, was added to make the cage flush with the stream bottom. Rocks $(N=10)$ were measured inside and outside the cage to ensure that substrate inside cages mimicked natural conditions. Cages (six in each of two habitats at three sites $=36$ cages total) were placed in the center of each riftle and pool. Initially, cages were open at the top for 2 wk to allow algae and invertebrates to colonize.

After $2 \mathrm{wk}$, two juvenile crayfish of each species (15-16 mm carapace length (CL), 1:1 male to female ratio) were added $(N=4$ crayfish per cage) and cages were covered with hardware mesh lids $\left(5 \mathrm{~mm}^{2}\right)$. This density $\left(16\right.$ individuals $\left.\cdot \mathrm{m}^{-2}\right)$ was higher than that normally encountered $(\bar{X}=8$ individuals $\left.\cdot \mathrm{m}^{-2}\right)$ but the total biomass per unit area in each cage $\left(21.1 \mathrm{~g} \cdot \mathrm{m}^{-2}\right)$ was within the natural range found in central Ohio streams $\left(0.0-27.6 \mathrm{~g} \cdot \mathrm{m}^{-2}\right)$. Before the experiment, crayfish were collected from nearby allopatric sites, measured (nearest $0.5 \mathrm{~mm}$ ), wiped quickly with a dry towel, weighed (nearest $0.001 \mathrm{~g}$ ), marked with acrylic paint, and isolated in individually marked, flow-through $7 \times 7 \mathrm{~cm}$ containers. Crayfish were fed lettuce ad libitum until experiments began. Orconectes rusticus and $O$. sanborni juveniles in each cage were exactly matched by length (nearest $0.1 \mathrm{~mm}$ ) to avoid any initial size advantage. Screens on cage ends and lids were cleaned every other day with a wire brush. Of the 36 cages, 30 remained in the stream during June-July 1988 (mean temperature $=15^{\circ} \mathrm{C}$ ). After 5 wk of growth, remaining crayfish were weighed and measured as described above.

\section{Habitat-Specific Mortality}

To quantify habitat-specific mortality, crayfish were tethered in riffles $(7-10 \mathrm{~cm}$ deep), shallow pools $(<40 \mathrm{~cm})$, and deep pools $(>40 \mathrm{~cm})$ at the same three sites. As with the growth experiments, all pools at this site had fish predators. Pools were divided by depth to separate the effects of deepwater predators (fish) from those of shallow-water predators, (wading birds, raccoons). A fourth treatment, set up in a laboratory stream tank, assessed tether loss. Because time and crayfish availability prevented the use of both species, only the native crayfish O. sanborni was tethered. Other experiments (Mather 1990) support the assumption that same-sized $O$. sanborni and $O$. rusticus suffer similar predatory mortality when movement is restrained.

Juvenile crayfish ( $15-16 \mathrm{~mm} \mathrm{CL}$ ) were held in the laboratory and fed lettuce, liver, and fish ad libitum for about $2 \mathrm{wk}$. In the laboratory, a small snap swivel was superglued to the dorsal midpoint of the carapace to which $20 \mathrm{~cm}$ of transparent monofilament line was tied. In the field, during October and November, juvenile crayfish were attached, via this line, to stakes, $1 \mathrm{~m}$ apart, set up along several transects that bracketed the center of each habitat. The area $1 \mathrm{~m}$ from shore was avoided to eliminate desiccation from water-level fluctuations. In both pools and riffles, all tethered crayfish had access to shelter, i.e. either large substate $(\bar{X}=12 \mathrm{~cm}$, longest side) or small substrate $(\bar{X}=3 \mathrm{~cm}$, longest side). Because substrate size did not affect survival, large and small shelter treatments were combined ( $t$-test on difference, $P>0.05$ ). For each of three replicates, 10 crayfish were tethered in the riffle and 20 crayfish in the pool ( 10 large shelter +10 small shelter).

To assess tether loss, crayfish, handled as above, were attached to a tile in riffles and pools of a laboratory stream tank (for a description, see Mather 1990). Tethered animals behaved normally (M. E. Mather, pers. obs.) as has been documented elsewhere (McIvor and Odum 1988; Hay et al. 1989). Each crayfish was checked at 2,5 , and $8 \mathrm{~d}$. No stakes were lost: no 
TABLE 2. Physical characteristics of sites used in caging experiments, tethering experiments, and field test. Manipulations tested growth (summer 1988) and mortality (fall 1989) in three riffles and three pools in Raccoon Creek (RAC). Field tests quantified habitat-specific crayfish size and density in South Fork of Licking River (SFL) and North Fork of Licking River (NFL). For density, two riffles and two pools were sampled in each river in both July and September 1988. For size, one riffle and one pool were sampled in each river in both July and September 1988. Predatory fishes included smallmouth bass (Micropterus dolomieu), rock bass (Ambloplites rupestris), and creek chub (Semotilus atroma. culatus $) \geqslant 150 \mathrm{~mm}$ total length.

\begin{tabular}{|c|c|c|c|c|c|}
\hline \multirow[b]{3}{*}{ River } & \multirow{3}{*}{$\begin{array}{l}\text { Mean predator } \\
\text { density } \\
\text { in pools } \\
\text { (no. } 500 \mathrm{~m}^{-2} \text { ) }\end{array}$} & \multicolumn{4}{|c|}{ Habitat } \\
\hline & & \multicolumn{2}{|c|}{ Riffle $(\bar{X})$} & \multicolumn{2}{|c|}{ Pool $(\bar{X})$} \\
\hline & & $\begin{array}{l}\text { Width } \\
(\mathrm{m})\end{array}$ & $\begin{array}{c}\text { Depth } \\
(\mathrm{m})\end{array}$ & $\begin{array}{l}\text { Width } \\
(\mathrm{m})\end{array}$ & $\begin{array}{c}\text { Depth } \\
(\mathrm{m})\end{array}$ \\
\hline $\mathrm{RAC}$ & 4.5 & 14.0 & 0.1 & 20.0 & 0.73 \\
\hline NFL & 0 & 7.7 & 0.1 & 8.6 & 0.45 \\
\hline SFL & 5.8 & 5.1 & 0.1 & 9.1 & 0.30 \\
\hline
\end{tabular}

tethers were broken. If the snap swivel had only a small piece of carapace attached, we assumed that the crayfish had been eaten by a predator. All tethered crayfish were held for $2 \mathrm{~d}$ in the laboratory before being placed in the stream. No molting was observed during this time or in trials of the stream tank treatment. Consequently, we believe that no crayfish escaped their tethers by molting during this field experiment. These tethering experiments were completed in October and November 1989 (at about $10^{\circ} \mathrm{C}$ ).

\section{Field Pattern}

To assess habitat-specific field patterns, we first calculated a cost-benefit ratio for $O$. sanborni (Werner and Gilliam 1984). To calculate the cost-benefit ratio for $O$. sanborn $i$, habitat-specific growth and mortality data from the above-described cage and tethering experiments were used. With this, we predicted crayfish habitat use. Next, using field sampling, crayfish density and size in each habitat were quantified. To document habitat-specific size and density, two second-order streams in the Licking River with sympatric crayfish populations were sampled. The South Fork of the Licking River (Licking County, Ohio) has a substantial fish predator population and the North Fork of the Licking River (Licking and Knox counties, Ohio) has no fish predators (Table 2).

Riffles and their adjacent pools were sampled by enclosing each with block nets; all of the riffles but only $17 \mathrm{~m}$ of the pool were sampled (resulting in similar riffle and pool sample areas). Enclosed areas were repeatedly kick-seined $(N=180 \mathrm{~min}$ effort per sample) and all crayfish collected, identified, and measured. In July and September 1988, at each site, one pool and one riffle were sampled for crayfish size $(N=1)$; at the same time, an additional riffle and pool $(N=2)$ were sampled for density. Crayfish density was analyzed using a three-way repeated measures analysis of variance (ANOVA) in which effects of fish, crayfish species, and habitat were tested. In this analysis, time was used as a repeated measure and the site populations were the experimental unit. Crayfish size was analyzed using a three-way ANOVA that tested the effects of fish, crayfish species, and habitat on log-transformed carapace lengths. Because crayfish size was measured at only one riffle and one pool, in the size analysis, the individual crayfish, not the site population, was the unit of measure. This analysis has limited generality but provides one opportunity to examine crayfish size distribution in the field. All effects discussed below were significant $(P<0.05)$.

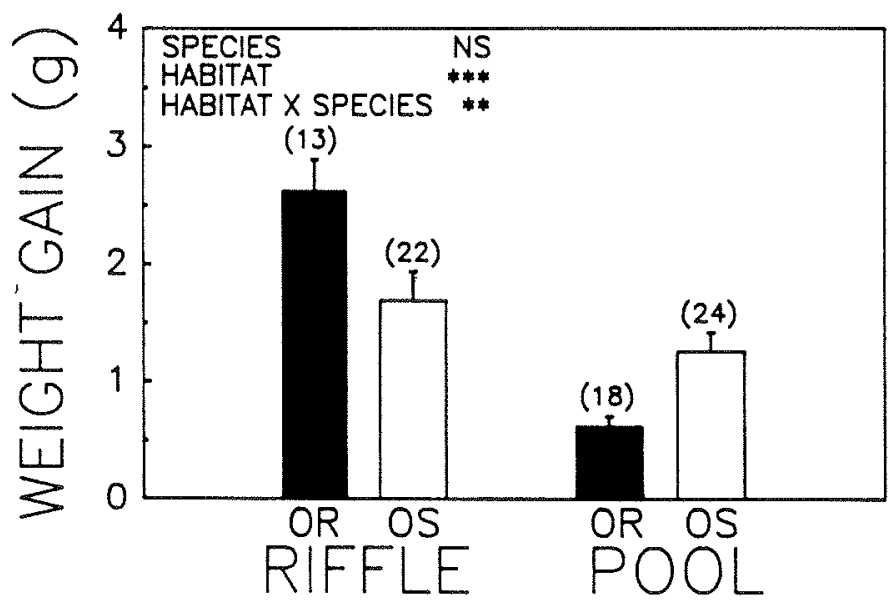

FIG. 1. Weight gain of juvenile ( $15 \mathrm{~mm} \mathrm{CL)} \mathrm{O.} \mathrm{rusticus} \mathrm{(OR)} \mathrm{and}$ $O$. sanborni (OS) during 5 wk during June-July 1988 in riffles and pools of Raccoon Creek, Licking County, Ohio. Data are means $\pm 1 \mathrm{SE}$. Crayfish were recovered from 30 cages. Numbers of crayfish remaining at experiment's end are in parentheses; initially, 30 of each species were placed in each habitat. Because growth among the three locations within Raccoon Creek did not differ (ANOVA, $P>0.05$ ), data from all sites were combined. See Table 3 for the results of twoway ANOVA used to assess how species and habitat influence growth. ${ }^{*} P \leqslant 0.05 ;{ }^{* *} P \leqslant 0.001 ;{ }^{* * *} P \leqslant 0.0001$. Increases in length and weight yielded similar conclusions, so only weight data were presented.

\section{Results and Discussion}

Growth

Results

From cage experiments, two important results emerged. First, riffle crayfish, regardless of species, grew more rapidly than pool crayfish (Fig. 1; Table 3). Second, the invader $O$. rusticus grew faster than the native $O$. sanborni in riffles and more slowly than $O$. sanborni in pools (Fig. 1; Table 3).

\section{Discussion}

Either food quantity or food quality may permit riffle-dwelling crayfish to grow faster than pool-dwelling ones. As opportunistic omnivores consuming mollusks (Covich et al. 1981; Crowl and Covich 1990; Alexander and Covich 1991), aquatic insects (Lorman 1975; Capelli 1980), macrophytes (Lorman 1975), algae (Capelli 1980), leaf litter (Huryn and Wallace 
Taв1.: 3. Main effects and tirst-order interactions of ANOVA measuring how species and habitat influence weight gain of $O$. rusticus and $O$. samborni during a 5-wk cage experiment in Raccoon Creek. Licking County. Ohio, during June-July 1988. ${ }^{*} P \leqslant 0.05 ;{ }^{* *} P \leqslant 0.001 ;{ }^{* *} P \leqslant 0.0001$. Data correspond to Fig. 1. Overall degrets of freedom are as follows: model $\mathrm{df}=3$; error $\mathrm{df}=73$ : total corrected $d f=76$. Overall ANOVA SS $=32.19$.

\begin{tabular}{llcll}
\hline \multicolumn{1}{c}{ Effect } & df & SS & \multicolumn{1}{c}{$F$} & \multicolumn{1}{c}{$P$} \\
\hline Species & 1 & 00.37 & 00.47 & 0.49 \\
Habitat & 1 & 26.74 & 33.40 & $0.0001^{* * *}$ \\
Species $\times$ habitat & 1 & 11.23 & 14.45 & $0.003^{* *}$ \\
\hline
\end{tabular}

1987b), and juvenile crayfish (Capelli 1980), crayfish diet varies with season, depth, size, and sex (Lorman 1975; Capelli 1980). However, crayfish are not indiscriminate foragers (Lorman 1975). Animal matter contains more calories per gram than plant material and often more stream insects occur in riffles than pools (Schlosser 1987; Schlosser and Ebel 1989; True 1990). At our sites, True (1990) found that riffle crayfish of both species consumed more macroinvertebrates than pool crayfish. Thus, when confined to cages, food quality was likely responsible for the high growth of riffle crayfish. Although cages may have reduced current velocity slightly, velocities inside cages were within the range in natural riffles. Hence, cages themselves were not the cause of these trends.

Although $O$. rusticus and $O$. sanborni did not differ in overall growth, $O$. rusticus grew faster than $O$. sanborni in riffles and more slowly than $O$. sanborni in pools. These growth differences could be caused by ecological, behavioral, or physiological mechanisms. First, when free-ranging, the invader $O$. rusticus actively selects more heptageniids, a large riffle invertebrate, than does $O$. sanborni (True 1990). Thus, the invader may be attaining a larger size in the riffle by differentially exploiting high-quality riffle food. Second, $O$. rusticus is more active than $O$. sanborni in a laboratory-simulated stream (Mather 1990); similarly, unrestrained $O$. rusticus feed at a higher rate than native crayfish (Butler and Stein 1985; True 1990). Both of these findings suggest that higher overall activity and more efficient foraging behavior may help $O$. rusticus exploit the riffle more efficiently and thereby grow faster. Orconectes rusticus, the innately more active species (Mather 1990), also may have a higher overall metabolic rate which allows this invader to take advantage of a good habitat but which extracts higher maintenance costs, thereby limiting growth, in less profitable habitats. That the native $O$. sanborni grows faster than $O$. rusticus in pools, the habitat where risk from fish predation is high, also could have important implications for the replacement.

Some mortality occurred in growth cages (see Fig. 1). This mortality, of unknown causes, occurred across all cages. Hence, density did not differ across treatments and did not contribute to growth differences. In summary, the growth difference between crayfish species likely occurs because $O$. rusticus (1) eats higher quality food, (2) feeds more actively, and (3) maintains a higher metabolism. In another system, differential feeding efficiency also contributed to a species replacement (McComas and Drenner 1982). In Ohio streams, O. rusticus exploited high-growth riffles better than $O$. sanborni and grew larger; thus differential growth likely contibutes to the replacement of $O$. sanborni by $O$. rusticus.

\section{Mortality}

\section{Results}

In the laboratory-simulated stream, no crayfish broke their tethers. More craytish died in deep pools than in shallow pools

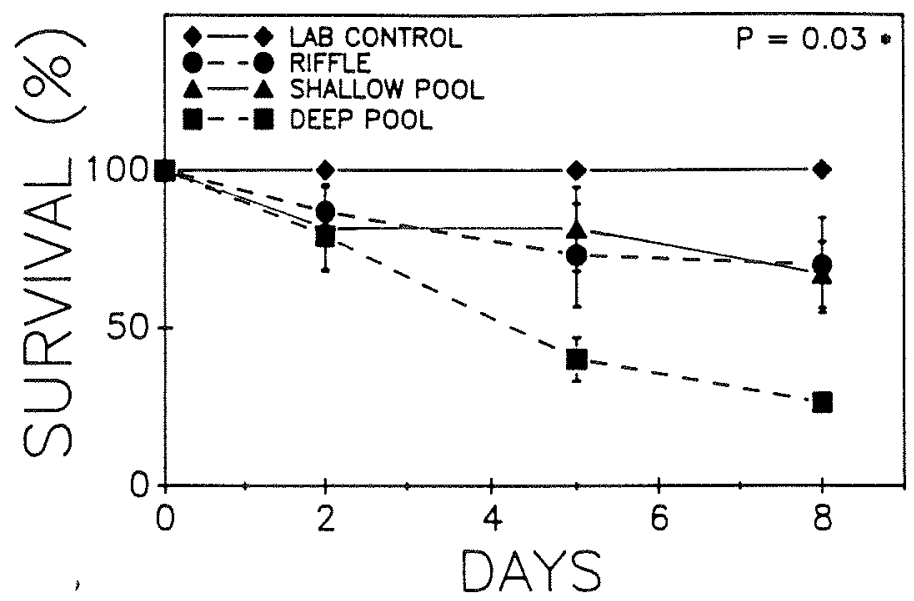

Fig. 2. Survival of juvenile $O$. samborni $(N=10-20$ crayfish per habitat for each of three replicates) tethered in riffles $(7-14 \mathrm{~cm})$, shallow pools $(<40 \mathrm{~cm})$, deep pools $(>40 \mathrm{~cm})$, and a laboratory stream tank during $8 \mathrm{~d}$ in fall 1989. Data are means \pm 1 SE. Because survival in the three sites within Raccoon Creek did not differ (ANOVA, $P>0.05$ ), data from all sites were combined. The results of a repeated measures ANOVA using time as the repeated measure and assessing how habitat influenced survival are indicated.

or riffles (Fig. 2, ANOVA, $\mathrm{SS}=4347.6, F=6.5$, $P=0.03$ ). Survival in the two shallow-water habitats did not differ (Fig. 2) but more crayfish died in these habitats than in the laboratory stream tank.

\section{Discussion}

Predators (fish, avian, and mammalian) may influence habitat use. For example, without fish predators, juvenile stream fishes of all taxa reviewed by Schlosser (1987) prefer stream pools, but with predators they occur mostly in riffles. Similarly, armored catfish avoid the food-rich shallow areas of a Panamanian stream, probably because bird predators occur inshore (Power 1984). In our study, deepwater mortality was caused by fish predators; terrestrial predators, i.e. wading birds and racoons, most likely caused the mortality in shallow pools and riffles. Shelters may modify risks, but all tethered crayfish had access to shelter and, regardless, many were eaten. Hence, for crayfish, predation risk may be an ever-present danger. At out study site, deep pools, where fish predators live, were more dangerous for juvenile crayfish than shallow-water habitats, where avian and mammalian predators forage. Conversely, at other sites with large populations of terrestrial predators and no fish predators, riffles and shallow pools could be the most dangerous habitat. Clearly, the relative importance of each type of predation varies spatially and temporally with changes in the vertebrate community.

Because only $O$. sanborni was tethered, habitat-specific mortality can be calculated only for this native crayfish. However, we can speculate about mortality of $O$. rusticus. Only 
TABLE 4. Ratio of mortality (proportion dead through 8 d; see Fig. 2) to growth (weight gain in $\mathrm{g} \cdot 8 \mathrm{~d}^{-1}$; see Fig. 1) for riffles and pools in Raccoon Creek, a second-order Ohio stream with predatory fishes. Mortality was assessed from field experiments (fall 1989) for $O$. sanborni. Growth was measured in cage experiments for both species in summer 1988. $\mathrm{OR}=O$. rusticus; $\mathrm{OS}=O$. sanborni. (Note: theory predicts that animals should minimize the mortality/growth ratio.)

\begin{tabular}{lcclll}
\hline \hline & \multicolumn{2}{c}{ Riffle } & & \multicolumn{2}{c}{ Pool } \\
\cline { 2 - 3 } \cline { 6 - 7 } & OR & OS & & OR & OS \\
\hline Mortality & $\overline{n n n n y y}$ & 0.25 & & - & 0.75 \\
Growth & 0.52 & 0.35 & & 0.12 & 0.25 \\
Mortality/growth & - & 0.71 & & - & 3.00 \\
\hline
\end{tabular}

three outcomes are possible: $O$. rusticus could suffer (1) higher, (2) equal, or (3) lower mortality than the native. No evidence (reviewed below) exists that $O$. rusticus is more susceptible to predators than native orconectid crayfish; hence, this first possible outcome can be dismissed. Same-sized $O$. rusticus and $O$. sanborni are equally vulnerable to smallmouth bass (Micropterus dolomieu, previously Micropterus dolomieui) predation in one study in a simulated stream tank (Mather 1990). However, in another study using aquaria, large, youngof-year $O$. rusticus $(14 \mathrm{~mm} \mathrm{CL}$ ) survived bass predation better than small $O$. sanborni (12.5 mm CL; Butler and Stein 1985). Because larger $(3.5 \mathrm{~mm})$ young-of-year $O$. rusticus are eaten less often than smaller O. sanborni (Mather 1990), these last results may also reflect a size rather than a species effect. However, from these existing data, whether $O$. rusticus is equally or less vulnerable than $O$. sanborni is unclear. Thus, in our discussion, we will assume that the invader $O$. rusticus suffers either similar or lower predatory mortality than $O$. sanborni.

\section{Field Pattern}

\section{Predictions}

Using our assessment of costs and benefits based on fish predators and food, the ratio of mortality to growth was minimized in riffles (Table 4). Thus, based on food and fish predation, for the native $O$. sanborni, the riffle should be a fourfold more profitable habitat than the pool.

\section{Discussion}

Others have found that foragers trade off energetic return and predation risk when these two factors conflict (Sih 1980; Werner et al. 1983a; Werner and Hall 1988). How foragers assess these trade-offs is not clear. They may evaluate food and danger independently (Cerri and Fraser 1983), simultaneously (Werner and Gilliam 1984; Gilliam and Fraser 1987), or using a repertoire of flexible responses (Holbrook and Schmitt 1988). Based on growth and mortality as measured here, crayfish should preferentially occupy riffles.

Our prediction that the riffle is the most energetically profitable habitat, we believe, accurately reflects habitat-specific costs and benefits to juvenile crayfish based on food and fish predators. For many organisms, habitat use can be accurately predicted by examining only these two factors (Cerri and Fraser 1983; Werner et al. 1983a; Gilliam and Fraser 1987; Holbrook and Schmitt 1988). Hence, the assumption that food and fish predators are of critical importance is a reasonable one. The field data that we used for our predictions are strong. Thus, agreement between field data and our predictions will confirm the overwhelming importance of these factors; disagreement between field data and our predictions, in turn, will demon-

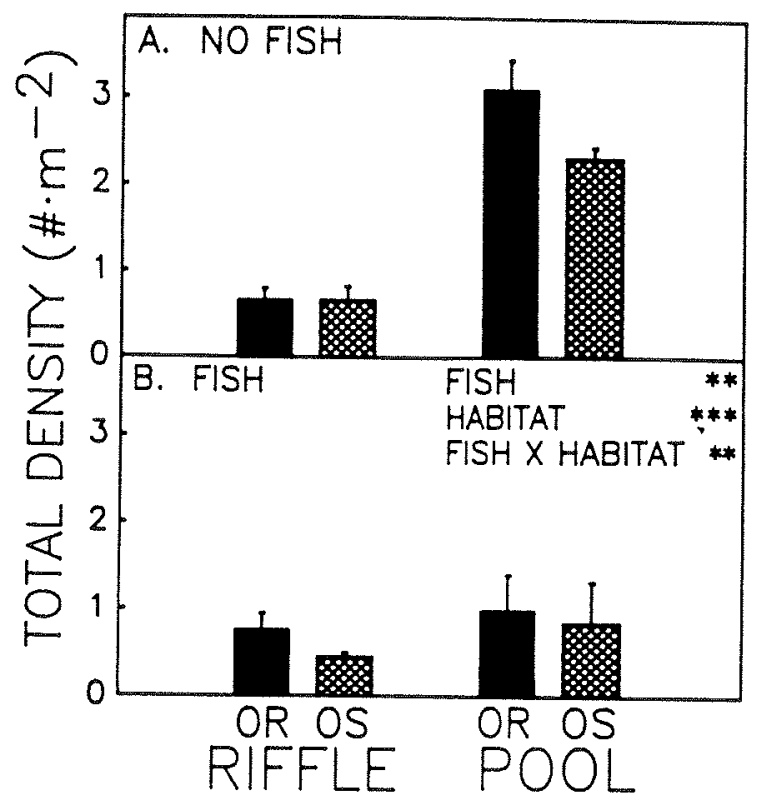

FIG. 3. Density of $O$. rusticus (OR) and $O$. sanborni (OS) in riffles and pools collected during a field test of sites (A) without fish predators (North Fork of the Licking River, Licking and Knox counties, Ohio) and (B) with fish predators (South Fork of Licking River, Licking County, Ohio) during July-September 1988. Data are means $\pm 1 \mathrm{SE}$. Two replicates of each habitat at each site were sampled at two times. The results of a repeated measures ANOVA that tested the effect of habitat, species, and fish treatment (see Table 5) are indicated; ${ }^{*} P \leqslant 0.05 ; * * P \leqslant 0.001 ; * * * P \leqslant 0.0001$

strate that other growth and mortality factors play a central role in juvenile crayfish habitat choice.

Field Pattern: Density

Results

Crayfish did not shift into the riffle when fish were present as we predicted (Fig. 3). Rather, crayfish densities were greatest in pools for both species with and without fish (Fig. 3; Table 5). Overall densities were lower with fish primarily because pool densities with fish were lower than pool densities without fish (Fig. 3; Table 5).

\section{Discussion}

Based on cage/tethering experiments, juvenile crayfish should select the high-growth, low-predation-risk riffles. Consequently, higher crayfish densities should occur in riffles especially with fish predators in pools. However, both with and without fish, for both species, pool densities exceeded riffle densities. Why did our cage/tethering experiments provide so little insight into crayfish habitat choice? First, position maintenance in riffles may require substantial energy. For juvenile fish, for example, costs of foraging in riffles outweigh benefits (Schlosser 1987). Second, fast current in riffles may increase the probability of passive drift. Although $O$. rusticus is more streamlined than O. propinquus (Maude and Williams 1983), water velocity may still constrain high occupancy of the riffle. When a crayfish loses its footing in the riffle, often as a result of inter- or intraspecific aggression, it passively drifts. As a result, the probability of consumption by fish in downstream pools is substantially increased. In our simulated stream tank, predation following passive drift was frequently observed (Mather 1990). Third, terrestrial predators may deter crayfish from inhabiting riffles. In summary, we believe that juvenile 
TAiste 5. Main effects and first-order interactions of ANOVA testing how fish, species, habitat, and time affect total craytish density in the South and North forks of the Licking River (Licking and Knox counties, Ohio) during June-September 1988 . Higher order interactions were not significant. ${ }^{*} P \leqslant 0.05$; ${ }^{* *} P \leqslant 0.001: * * * P \leqslant 0.0001$. Data correspond to Fig. 3. Overall degrees of freedom are as follows: model $\mathrm{df}=14$ : error $\mathrm{df}=17 ;$ corrected total $\mathrm{df}=31$. Overall ANOVA SS $=32.15$.

\begin{tabular}{lcrrl}
\hline \multicolumn{1}{c}{ Effect } & df & SS & \multicolumn{1}{c}{$F$} & \multicolumn{1}{c}{$P$} \\
\hline Fish & 1 & 6.69 & 19.75 & $0.0004^{* *}$ \\
Species & 1 & 0.76 & 2.25 & 0.15 \\
Habitat & 1 & 11.00 & 32.49 & $0.0001^{* * *}$ \\
Time & 1 & 0.24 & 0.72 & 0.41 \\
Fish $\times$ species & 1 & 0.06 & 0.16 & 0.70 \\
Fish $\times$ habitat & 1 & 5.88 & 17.36 & $0.0006^{* *}$ \\
Fish $\times$ time & 1 & 0.17 & 0.52 & 0.48 \\
Species $\times$ habitat & 1 & 0.18 & 0.53 & 0.48 \\
Species $\times$ time & 1 & 0.17 & 0.52 & 0.48 \\
Habitat $\times$ time & 1 & 0.28 & 0.84 & 0.37 \\
\hline
\end{tabular}

crayfish are not assessing habitat-specific benefits and costs using only food and fish predators. Other costs encountered in the riffle must outweigh advantages associated with high food quality and refuges.

\section{Field Pattern: Size}

Results

The invader $O$. rusticus was larger than the native O. sanborni within each site (Fig. 4A; Table 6), within each habitat (Fig. 4B; Table 6), and especially in riffles at the site with fish predators (Fig. 4B). At the site with fish predators, crayfish size was reduced overall (Fig. 4A; Table 6) and for both species (Fig. 4B; Table 6). At the site with fish predators, riffle crayfish were larger than pool crayfish (Fig. 4B; Table 6); without fish predators, this trend was reversed and riffle crayfish were smaller than pool crayfish (Fig. 4B; Table 6).

\section{Discussion}

Unlike our cage results, species sizes consistently differed in the stream; in all comparisons, $O$. rusticus was larger than $O$. sanborni. As in cages, this difference was most pronounced in riffles and at the site with fish. An overall difference would appear in the field samples, but not necessarily within the confines of field cages, if $O$. rusticus is more active and forages over wider areas (Mather 1990). Hence, O. rusticus may attain its larger size, in part, via increased foraging efficiency in both riffles and pools.

Our field data demonstrate that variation exists in crayfish size both with predation intensity and between habitats. At the site with fish predators, crayfish were smaller. Because size was measured at only one site with fish predators and one site without fish predators, we cannot generalize about the impact of fish predators on crayfish size and growth. However, other studies suggest that fish predators may negatively affect crayfish size. For example, fish predators (1) reduce crayfish activity and consequently feeding efficiency (Stein and Magnuson 1976; Mather 1990), (2) force crayfish into less profitable microhabitats (Stein 1977; True 1990), (3) may prevent crayfish from being active foragers on invertebrates (True 1990), and/or (4) selectively prey on certain sizes of crayfish (Stein 1977). All of these fish-induced effects will reduce crayfish size. Whether this trend applies to all sites with fish predators requires further examination.

How do the results from the field sampling compare with the crayfish size pattern in the growth experiments? As predicted by our experiments, at the site with fish, larger crayfish occu-

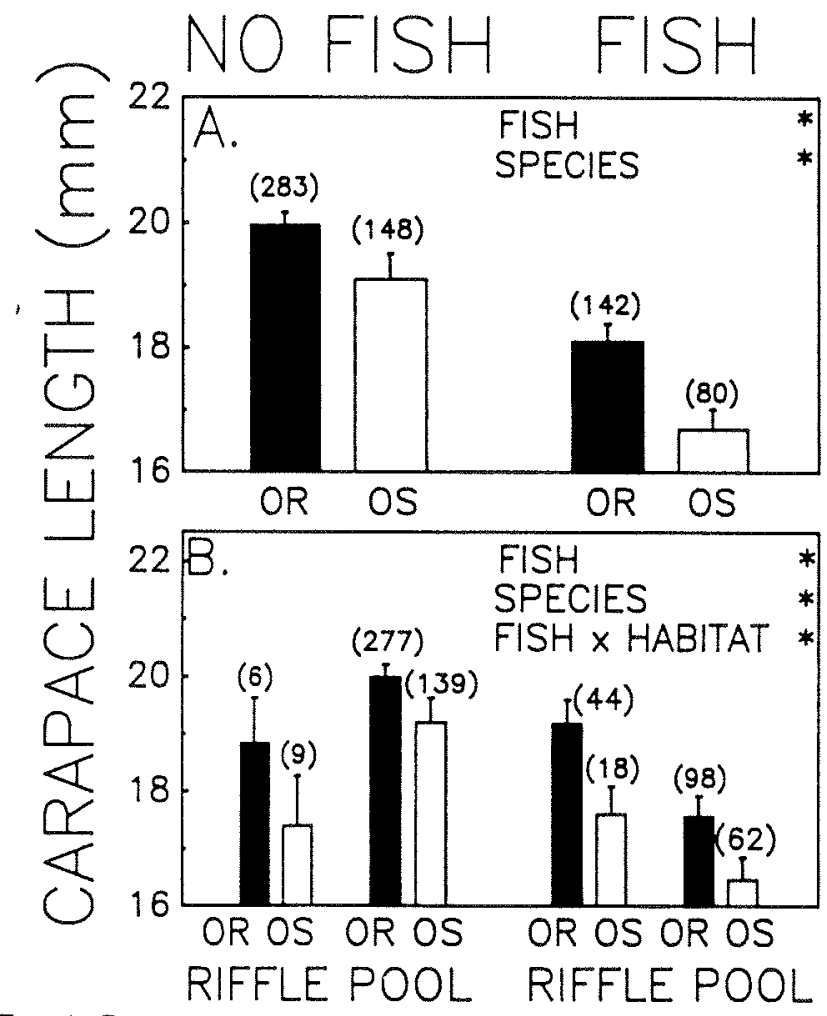

Fig. 4. Carapace length of $O$. rusticus and $O$. samborni in riffles and pools without fish predators (North Fork of the Licking River, Licking and Knox counties) and with fish predators (South Fork of Licking River, Licking County, Ohio) during July-September 1988. (A) Effects of fish predators on carapace length of $O$. rusticus and $O$. sanborni (pools and riffles combined); (B) effect of fish on carapace length of $O$. rusticus and $O$. sanborni in riffles and pools. For both panels, bars on the left half show sites without fish and bars on the right half show sites with fish. Data are means $\pm 1 \mathrm{SE}$. The experimental unit is the individual crayfish. Sample size is indicated in parentheses. Results of a three-way ANOVA are presented (Table 6); ${ }^{*} P \leqslant 0.05 ;{ }^{* *} P \leqslant 0.001 ;{ }^{* * *} P \leqslant 0.0001$. Note that the $\mathrm{y}$-axis does not begin at zero.

pied riffles, but at the site without fish, smaller crayfish occupied riffles. Free-ranging pool crayfish likely consume more food than pool crayfish constrained by either fish predators or cages. Growth is only one measure of habitat quality and other factors also may be important; but by assessing habitat on this factor alone, two trends emerge: (1) foraging efficiency of pool 
TABLE 6. Main effects and first-order interactions of ANOVA testing how fish, species, and habitat influence craytish size (carapace length) in the South and North forks of the Licking River (Licking and Knox counties, Ohio), during June-September 1988. Higher order interactions were not significant. ${ }^{*} P \leqslant 0.05$. Data correspond to Fig. 4 . Overall degrees of treedom are as follows: model df $=7$; error $\mathrm{df}=$ 645; corrected total $d f=652$. Overall ANOVA $S S=929.18$.

\begin{tabular}{llrrl}
\hline \multicolumn{1}{c}{ Effect } & df & \multicolumn{1}{c}{ SS } & \multicolumn{1}{c}{$F$} & \multicolumn{1}{c}{$P$} \\
\hline Fish & 1 & 54.58 & 3.69 & $0.05^{*}$ \\
Species & 1 & 59.76 & 4.04 & $0.04^{*}$ \\
Habitat & 1 & 0.06 & 0.00 & 0.95 \\
Fish $\times$ habitat & 1 & 81.56 & 5.51 & $0.02^{*}$ \\
Fish $\times$ species & 1 & 0.64 & 0.04 & 0.84 \\
Species $\times$ habitat & 1 & 2.92 & 0.20 & 0.66 \\
\hline
\end{tabular}

crayfish may be reduced with fish and (2) both food quantity and food quality are important to free-ranging crayfish.

\section{Conclusions}

\section{Role of Habitat}

In habitats with fish, these predators probably affect crayfish in two ways. First, fish may reduce crayfish survival by consumption. Second, fish may reduce crayfish growth by altering crayfish activity and foraging efficiency. Crayfish growth was higher and predatory mortality was lower in riffles with fish predators. But apparently, costs unrelated to fish predators may negate advantages associated with this habitat because we found more crayfish in pools than in riffles throughout the field samples (two pools + two riffles per stream $\times$ two streams $=$ eight riffle pool complexes, each sampled twice). Specifically, terrestrial predators may be an important source of mortality for crayfish in some streams. Not only do birds and mammals focus on a different habitat (shallow pools and riffles vs deep pools), but unlike gape-limited fish predators, they likely select the largest adult crayfish. Thus, when terrestrial predators are abundant, crayfish do not enjoy a size refuge and terrestrial predators will have different effects on habitat-specific crayfish densities and sizes than fish predators. Dangers associated with high current (passive drift, physiological costs, drying during the summer and resultant density-dependent interactions, cannibalism, etc) also may be important in habitat choice of juvenile crayfish. The highgrowth, low-mortality riffle may be a good place to be only if (1) terrestrial predators are limited, (2) position can be maintained, and (3) aggression can be repelled. Riffles may act simply as nursery areas in which juveniles grow through their window of vulnerability to fish predators.

\section{Role of Species}

The replacement of native crayfish by $O$. rusticus has been widely studied. The first studies documented the unambiguous initial pattern, i.e. $O$. rusticus was introduced, became established immediately, and rapidly increased in number whereas native crayfish abundances declined concurrently (Turner 1926; Rhoades 1944, 1962; Crocker and Barr 1968; Berrill 1978; Capelli 1982; Jezerinac 1982). In the next group of studies, mechanisms for this seemingly simple field pattern were sought. The roles of abiotic factors (Capelli and Magnuson 1983; Flynn and Hobbs 1984), reproductive interference (Capelli and Capelli 1980; Tierney and Dunham 1984; Butler and Stein 1985), and competition (Capelli and Munjal 1982; Flynn and Hobbs 1984; Butler and Stein 1985) were examined. Although each of these factors provides partial information about mechanisms, exactly how $O$. rusticus replaces its congeners is still unclear.

The role of interspecific competition in the replacement, especially, has received wide attention. Species-specific differences in competitive ability exist among orconectid crayfish (Bovbjerg 1970; Capelli and Munjal 1982). In the field, $O$. rusticus has increased at the expense of native crayfishes in just $5 \mathrm{yr}$ in several Wisconsin lakes (Capelli 1982). But in Ohio, $O$. sanborni, a native more aggressive than other native crayfishes, can hold its own with $O$. rusticus when equal sized. This even match between Ohio crayfish species may explain why, in central Ohio streams, the replacement has not led to the rapid extirpation of $O$. sanborni in sympatric systems.

The third wave of studies (Butler and Stein 1985; Lodge et al. 1986) showed that long-term interactions between $O$. rusticus and native crayfish were complex and subtle. This $O$. rusticus - native crayfish replacement, initially classified as straightforward, now appears to have multiple causes and a variety of outcomes depending on the native crayfish species and systemspecific characteristics (Mather 1990; Olsen et al. 1991).

\section{Role of Size}

Why is $O$. rusticus consistently larger than $O$. sanborni? Orconectes rusticus is a more efficient forager in both riffle and pool. In addition, $O$. rusticus juveniles leave the female $2 \mathrm{wk}$ before other orconectid crayfishes, although female $O$. rusticus oviposits simultaneously with other orconectid crayfish (Corey 1988). In other systems, size-structured interactions influence physiological responses, feeding rate, competitive ability, and susceptibility to predation in phytoplankton, zooplankton, and fish (Stein et al. 1988). For crayfish, size confers an advantage in survival (Stein 1977) and reproduction (Stein 1976). Juveniles and adults often segregate by habitat. These life stages may segregate in response to differences in feeding efficiency and vulnerability to predators (Brandt 1980; Mittelbach 1981; Schlosser 1982; Baltz and Moyle 1984; Sandheinrich and Hubert 1984; Moyle and Vondracek 1985). In addition, cannibalistic adults may force juveniles into energetically less profitable habitats (Fraser and Cerri 1982; Rabeni 1985; Kneib 1987; Foster et al. 1988). Large crayfish are extremely aggressive and cannibalistic toward small crayfish (Mather 1990). In fact, in our system, large crayfish $(>25 \mathrm{~mm} \mathrm{CL}$ ) increase activity, habitat changes, fights, and swimming escapes of small crayfish (15 mm CL; Mather 1990). In our field samples, invulnerable crayfish $(>25 \mathrm{~mm} \mathrm{CL})$ were distributed relatively evenly throughout all habitats (Mather 1990). Hence, in our field study, the adult threat was ubiquitous; small crayfish could not escape large ones by simply shifting habitats (Mather 1990). Orconectes sanborni, more susceptible to large-crayfish aggression both because of smaller size and inherent species characteristics (Mather 1990), should suffer most from aggression, regardless of habitat.

\section{Potential Mechanisms for the Replacement}

Orconectus rusticus appears to grow faster in the riffle and be larger across both habitats. Because increased size also reduces vulnerability to predation (Mather 1990), all factors that lead to larger size of $O$. rusticus including habitat use, foraging behavior (greater food consumption and more heptageniids in the diet), and life history (earlier escape from the female) are important. Thus, habitat use, via size-structured interactions, contributes to the replacement of $O$. sanborni by O. rusticus. 


\section{Acknowledgements}

Many people contributed to the completion of this research. Bob Essman and Robert Grandstaff allowed us to work in their streams. A National Science Foundation Dissertation Improvement Grant, Sigma $\mathrm{Xi}$, and the Ohio Cooperative Fish and Wildlife Research Unit provided support for this research. Dave Armstrong, Tony Minamyer, Paul Minillo, and Paula Edersheim provided technical assistance. Jay Callender loaned us his house during the growth experiments. We thank Jim Mather and all members of the Aquatic Ecology Laboratory for their help. Comments by Andy Tumer, Billie Kerans, Nick Collins, Alan Covich, and two anonymous reviewers improved the manuscript.

\section{References}

Alexander, J. E., AND A. P. Covich. 1991. Predation risk and avoidance behavior in two freshwater snails. Biol. Bull. 180: 387-393.

BALTZ, D. M.. AND P. B. MorLE. 1984. Segregation by species and size classes of rainbow trout Salmo gairdneri and Sacramento sucker Catastomus occidentalis in three California streams. Environ. Biol. Fishes 10: 101-110.

BERRILL, M. 1978. Distribution and ecology of crayfish in the Kawartha lakes region of southern Ontario. Can. J. Zool. 56: 166-177.

BOVBJERG, R. V. 1970. Ecological isolation and competitive exclusion in two crayfish, Orconectes virilis and Orconectes immunis. Ecology 51: 225-

BRANDT, S. B. 1980. Spatial segregation of adult and young-of-year alewives across a thermocline in Lake Michigan. Trans. Am. Fish. Soc. 109: 469 478.

BUTLER, M. J., AND R. A. STEIN. 1985. An analysis of the mechanisms governing species replacement in crayfish. Oecologia 66: 168-177.

CAPELLI, G. M. 1980 . Seasonal variation in the food habits of the crayfish
Orconectes propinquus (Girard) in Orconectes propinquus (Girard) in Trout Lake, Villas County, Wisconsin, U.S.A. (Decapoda, Astacidea, Cambaridae). Crustaceana 38: 82-86.

1982. Displacement of norhem crayfish by 0 . rusticus (Girard). Limnol. Oceanogr. 27: 741-745.

CAPELLI, G. M., AND J. F. CAPELLI. 1980. Hybridization between crayfish of the genus Orconectes: morphological evidence (Decapoda: Cambaridae) Crustaceana 39: 121-132.

CAPELLI, G. M., AND J. J. MaGnuson. 1983. Morphoedaphic and biogeographic analysis of crayfish distribution in northern Wisconsin. J. Crustacean Biol. 3: 548-564.

CAPELLI, G. M., AND B. L. MUNJAL. 1982. Aggressive interactions and resource competition in relation to species displacement among crayfish of the genus Orconectes. J. Crustacean Biol. 2: 486-492.

CERRI, R. D., AND D. F. Fraser. 1983. Predation and risk in foraging minnows: balancing conflicting demands. Am. Nat. 121: 552-561

COOPER, S. D. 1984. The effects of trout on water striders in stream pools Decologia 63: 376-379.

COREY, S. 1988. Comparative life-histories of two populations of the introduced crayfish Orconectes rusticus (Girard 1985) in Ontario. Crustaceana 55: $29-38$

Covich, A. P.. L. L. DYE, AND J. S. Mattice. 1981. Crayfish predation on Corbicula under laboratory conditions. Am. Midl. Nat. 105: 181-188.

CROCKER, D. W., AND D. W. BARR. 1968. Handbook of the crayfishes of Ontario. Misc. Publ. R. Ont. Mus. University of Toronto Press, Downsview, Ont. $158 \mathrm{p}$.

Crowl. T., AND A. P. CoviCh. 1990. Predator-induced life-history shifts in a freshwater snail. Science (Wash., DC) 247: 949-951

DILL, L. M. AND A. G. FRASER. 1984. Risk of predation and the feeding Soc 16: 65-71. Soc. 16: 65-71.

DiXON, S. M., AND R. L. BAKER. 1988. Effects of size on predation risk, behavioral response to fish, and cost of reduced feeding in larval Ischnura verticalis (Coenagrionidae: Odonata). Oecologia 76: 200-205.

FLYNN, M. F.. AND H. H. HOBBS. 1984. Parapatric crayfishes in southern Ohio: evidence of competitive exclusion? J. Crustacean Biol. 4: 382-389.

Foster. S. A., V. B. GARCIA, AND M. Y. TOWN. 1988. Cannibalism as the cause of an ontogenetic shift in habitat use by fry of the threespine stickleback. Oecologia 74: 577-580.

FRASER, D. F., AND R. D. CERRI. 1982. Experimental evaluation of predatorprey relationships in a patchy environment: consequences for habitat use patterns by minnows. Ecology 63: 307-313.

GILlLAM, J. F., AND D. F. Fraser. 1987. Habitat selection under predation hazard: test of a model with foraging minnows. Ecology 68: 1856-1862.
Hay, M. E. J. R. PAWLIK, J. E. DufFy, and W. Fenical. 1989. Seaweedherbivore-predator interactions: host-plant specialization reduces predation on small herbivores. Oecologia $81: 418-427$

HOLBROOK, S. J., AND R. J. SCHMITT. 1988. The combined effects of predation risks and food reward on patch selection. Ecology 69: 125-134.

HolomUzKI, J. R. 1986. Predator avoidance and diel patterns of microhabitat use by larval tiger salamanders. Ecology 67: 737-748.

HOLOMUZKi. J. R., AND T. M. SHORT. 1988. Habitat use and fish avoidance behaviors by the stream-dwelling isopod. Lirceus fontinalis. Oikos 52 : $79-86$.

HURYN, A. D., AND J. B. WALLACE. 1987a. Local geomorphology as a determinant of macrofaunal production in a mountain stream. Ecology 68 : 1932-1942.

1987b. Production and litter processing by crayfish in an Appalachian mountain stream. Freshwater Biol. 18: 277-286

JEZERINAC, R. F. 1982. Life history notes and the distribution of crayfishes (Decapoda: Cambaridae) from the Chagrin River Basin, Northeastern Ohio. Ohio J. Sci. 82: $181-192$.

KNEIB, R. T. 1987. Predation risk and use of intertidal habitats by young fishes and shrimp. Ecology 68: 379-386

LODGE, D. M. . T. K. KRATZ, AND G. M. CAPELLI. 1986. Long-term dynamics of three crayfish species in Trout Lake, Wisconsin. Can. J. Fish. Aquat. Sci. 43: 993-998.

LORMAN, J. L. 1975. Feeding and activity of the crayfish, Orconectes rusticus in a northem Wisconsin lake. M.S. thesis, University of Wisconsin, Madison, WI. $56 \mathrm{p}$.

MATHER, M. E. 1990. Mechanisms of a species replacement in a benthic stream community. Ph.D. dissertation, The Ohio State University, Columbus, OH. $162 \mathrm{p}$

MAUdE, S. H., AND D. D. Williams. 1983. Behavior of crayfish in water currents: hydrodynamics of eight species with reference to their distribution pattern in Southern Ontario. Can. J. Fish. Aquat. Sci. 40: 68-77.

MCCOMAS, S. R., AND R. W. Drenner. 1982. Species replacement in a reservoir fish community: silverside feeding mechanics and competition. Can. J. Fish. Aquat. Sci. 39: 815-821.

MClvor, C. C., AND W. E. ODUM. 1988. Food, predation risk, and microhabitat selection in a marsh fish assemblage. Ecology 69: 1341-1351.

MiLINSKI, M., AND R. HELLER. 1978. Influence of a predator on the optimal foraging behavior of sticklebacks (Gasterosteus aculeatus). Nature (Lond.) 275: $642-644$

MTTELBACH, G. G. 1981. Foraging efficiency and body size: a study of optimal diet and habitat use by bluegills. Ecology 62: 1370-1386.

MOYLE, P. B., AND B. VONDRACEK. 1985. Persistence and structure of the fish assemblage in a small California stream. Ecology $66: 1-13$.

Olsen, T. M.. D. M. Lodge, G. M. Capelli, and R. J. Hollihan. 1991. Mechanisms of impact of an introduced crayfish (Orconectes rusticus) on littoral congeners, snails, and macrophytes. Can. J. Fish. Aquat. Sci. 48: 1853-1861.

POWER, M. E. 1984. Depth distributions of armored catfish: predator-induced resource avoidance? Ecology 65: 523-528.

POWER, M. E., W. J. MatThews, AND A. J. STEwart. 1985. Grazing minnows, piscivorous bass, and stream algae: dynamics of a strong interaction. Ecology 66: 1448-1456.

PREJs, A. 1987. Risk of predation and feeding rate in tropical freshwater fishes: field evidence. Oecologia 72: 259-262.

RABENI, C. F. 1985. Resource partitioning by stream-dwelling crayfish: the influence of body size. Am. Midl. Nat. 113:20-29.

RASMUSSEN, J. B. 1987. The effect of the predatory leech. Nephelopsis obscura, on mortality, growth, and the production of chironomid larvae in a small pond. Oecologia 73: 133-138.

RHOADES, R. R. 1944. Further studies on distribution and taxonomy of Ohio crayfishes, and the description of a new subspecies. Ohio J. Sci. 44: 9599.

1962. Further studies on Ohio crayfish: cases of sympatry of stream species in Southern Ohio. Ohio J. Sci. 62: 27-33.

SANDHEINRICH, M. B., AND W. A. HUBERT. 1984. Intraspecific resource partitioning by yellow perch Perca flavescens in a stratified lake. Can. J. Fish. Aquat. Sci. 41: 1745-1752.

SCHLOSSER, I. J. 1982. Fish community structure and function along two habitat gradients in a headwater stream. Ecol. Monogr. 52: 395-414.

1987. The role of predation in age-, size-related habitat use by stream fishes. Ecology 68: 651-659.

SCHLOSSER, I. J., AND K. K. EBEL. 1989. Effects of flow regime and cyprinid predation on a headwater stream. Ecol. Monogr. 59:41-57.

SiH, A. 1980. Optimal behavior: can foragers balance two conflicting demands? Science (Wash. DC) 210: 1041-1043.

1982a. Optimal patch use: variation in selection pressure for efficient foraging. Am. Nat. 120: 666-685. 
1982b. Foraging strategies and the avoidance of predation by an aquatic insect Notonecta hoffmanni. Ecology 63: 786-796.

STEIN, R. A. 1976. Sexual dimorphism in crayfish chelae: functional significance linked to reproductive activities. Can. J. Zool. 54: 220-227.

1977. Selective predation, optimal foraging, and the predator-prey interaction between fish and crayfish. Ecology 58: 1237-1253.

StEIN, R. A., AND J. J. MAGNUSON. 1976. Behavioral response of crayfish to a fish predator. Ecology 57: 751-761.

Stein, R. A., S. T. Threlkeld, C. D. Sanderen, W. G. Sprules, L. Persson, E. E. WERNER, W. E. NEILL, AND S. 1. DODSON. 1988. Size structure interactions in lake communities, p. 161-179. In S. R. Carpenter [ed.] Complex interactions in lake communities. Springer-Verlag, New York. NY.

TIERNEY, A. J., AND D. W. DUNHAM. 1984. Behavioral mechanisms of reproIII: $304-310$.
TRUE, L. P. 1990. Food choice by native and introduced crayfish: evaluating a potential mechanism for replacement. Masters thesis, The Ohio State University, Columbus, $\mathrm{OH} .82 \mathrm{p}$.

TURNER, C. L. 1926. The crayfishes of Ohio. Ohio Biol. Surv. Bull. (No. 13) 3(3): 145-196.

WERnER, E. E., AND J. F. GILLIAM. 1984. The ontogenetic niche shift and species interactions in size-structured populations. Annu. Rev. Ecol. Syst. 15: 393-425.

WERNER, E. E., AND D. J. HALL. 1988. Ontogenetic habitat shifts in bluegill: the foraging rate - predation risk tradeoff. Ecology 69: 1352-1366.

Werner, E. E., J. F. GILliam, D. J. Hall, and G. G. MitTel.BaCh. 1983a. An experimental test of the effects of predation risk on habitat use in fish. Ecology 64: 1540-1548.

Werner, E. E., G. G. Mittelbach, D. J. Hall, and J. F. Gilluam: 1983 b. Experimental tests of optimal habitat use in fish: the role of relative habitat
profitability. Ecology $64: 1525-1539$. 